\title{
Impact of Financial Infrastructure on Financial Development
}

\author{
Assoc. Prof. PhD Dimitar Rafailov \\ University of Economics - Varna, Varna, Bulgaria \\ d.rafailov@ue-varna.bg
}

\begin{abstract}
Financial development is a major factor that determines the economic situation and income level in different countries. Improving the financial infrastructure is a prerequisite for a more developed financial sector and its impact is an important issue to explore. For this purpose, data from 149 countries for the period 2010 - 2017 are analyzed, outlining the main trends in the development of financial infrastructure around the world. The econometric analysis of panel data shows that financial infrastructure has a significant positive impact on financial development. The main conclusion is that the better financial infrastructure will have a beneficial effect on the financial system and economic development.
\end{abstract}

Keywords: financial infrastructure, financial development, financial system, financial institutions

JEL Code: O160, G000; doi:10.36997/IJUSV-ESS/2019.8.2.83

\section{Въведение}

Финансовото развитие е значим фактор, който директно влияе върху икономическия растеж, нивото на доходите и стабилността на икономиката. Множество изследвания свидетелстват, че страните с по-добре развити финансови системи имат по-бърз икономически растеж и са по-богати (Levine, 2005; Ang, 2008; Demirgüç-Kunt, Levine, 2008; Dabla-Norris, Srivisal, 2013). Положителното влияние на финансовото развитие се проявява в няколко направления. Първо, добре функциониращата финансова система намалява информационната асиметрия и осигурява ефективна алокация на капитала към най-добрите фирми и инвестиции. Второ, финансовата система упражнява допълнителен мониторинг и контрол, което подобрява управлението на фирмите. Трето, развитият финансов сектор осигурява инструменти и механизми за по-добре управление на риска, включително чрез неговото прехвърляне и диверсификация. Това позволява да се предприемат по-рискови начинания, което значително улеснява иновациите. Четвърто, финансовият сектор улеснява акумулирането на спестяванията от множество спестители, което дава възможност да се финансират по-мащабни дейности и по този начин се спестяват транзакционни разходи и се реализират икономии от мащаба. Пето, финансовата система, чрез парите и платежните услуги, намалява транзакционните разходи и улеснява размяната на продукти и активи, което увеличава икономическия растеж.

Развитието на финансовия сектор се определя от множество фактори включително история, традиции, провеждана икономическа политика, осигуряване на конкуренция и свобода на действие на участниците, адекватна собственост и управление на финансовите институции и др. Наред с посочените фактори, от съществено значение е и финансовата инфраструктура. Тя се дефинира като комплекс от правила, институции и системи, чрез който икономическите субекти планират, договарят и извършват финансови транзакции (Bossone, Mahajan, Zahir, 2003). Може да се формулира хипотезата, че по-добрата финансова инфраструктура ще води до по-силно финансово развитие. Основание за това е, че финансовата инфраструктура е предпоставка за по-ефективното функциониране на финансовата система, тъй като намалява транзакционните разходи и информационната асиметрия, осигурява по-силна защита на правата на инвеститорите, стимулира конкуренцията между финансовите институции и подпомага стабилността на финансовия сектор. 


\section{1. Глобални тенденции в развитието на финансовата инфраструктура}

За да се анализира финансовата инфраструктура, трябва да се отчита състоянието на нейните основни компоненти. Те съставят нейните две основни части - информационна и транзакционна инфраструктура (Smith, Walter, 2003). Информационният компонент обхваща счетоводните системи и стандарти, системите за кредитна информация (кредитни регистри и кредитни бюра) и рейтинговите агенции, а транзакционните елементи са правната система, системите за сключване и реализация на сделки (тьрговски, платежни и клирингови системи) и регулаторната система и механизми (Georgiev, Valkanov, 2014). На тази база Рафаилов разработва Индекс на финансовата инфраструктура (IFI), който дава количествена оценка за нивото на нейното развитие (Rafailov, 2018). Индексьт се изчислява като средна величина от девет показателя за различните компоненти на финансовата инфраструктура, съответно:

- За състоянието на информационната инфраструктура:

1) сила на стандартите за одит и отчетност оценени на база докладите Global Competitiveness Report (World Economic Forum, 2018);

2) дълбочина на кредитната информация (оценена на база проучването Doing Business (World Bank, 2018a).

- За развитието на транзакционната инфраструктура:

a) качество на правна система

3) защита на интересите на миноритарните акционери (оценена на база докладите Global Competitiveness Report (World Economic Forum, 2018);

4) сила на законовите права (оценена на база проучванията Doing Business (World Bank, 2018a);

5) върховенство на закона (оценена на база проучванията Worldwide Governance Indicators (World Bank, 2018b).

б) състояние на системите за сключване и реализация на сделки

6) финансови услуги отговарящи на нуждите на бизнеса (оценени на база докладите Global Competitiveness Report (World Economic Forum, 2018);

7) наличие на последните технологии (оценени на база докладите Global Competitiveness Report (World Economic Forum, 2018).

в) състояние на регулаторните системи

8) качество на регулациите (оценена на база проучванията Worldwide Governance Indicators (World Bank, 2018b);

9) регулиране на пазарите на ценни книжа (оценени на база докладите Global Competitiveness Report (World Economic Forum, 2018).

Всички показатели, както и общият индекс, се измерват по скала от 0 до 100, като поголемите стойности означават по-добро развитие на финансовата инфраструктура.

На база на наличните източници на информация (Global Competitiveness Report, Doing Business и Worldwide Governance Indicators) са събрани данни, които позволяват да се изчисли стойността на индекса IFI за 149 страни за периода 2010 г. - 2017 г.

Получените резултати показват, че състоянието на финансовата инфраструктура силно се различава в различните страни, което е отразено в табл. 1.

Таблица 1. Стойности на Индекса на финансовата инфраструктура (IFI) за периода 2010 г. - 2017 г.

\begin{tabular}{|l|l|c|c|c|c|l|c|c|c|}
\hline № & \multicolumn{1}{|c|}{ Страна } & $\begin{array}{c}\text { Средна } \\
\text { ст-ст }\end{array}$ & $\begin{array}{c}\text { Мини- } \\
\text { мум }\end{array}$ & $\begin{array}{c}\text { Макси- } \\
\text { мум }\end{array}$ & № & & \multicolumn{2}{c|}{ Страна } & \multicolumn{2}{c|}{$\begin{array}{c}\text { Средна } \\
\text { ст-ст }\end{array}$} & $\begin{array}{c}\text { Мини- } \\
\text { мум }\end{array}$ & $\begin{array}{c}\text { Макси- } \\
\text { мум }\end{array}$ \\
\hline 1 & Нова Зеландия & 85,31 & 81,32 & 88,69 & 76 & Гана & 54,70 & 51,52 & 61,27 \\
\hline 2 & Сингапур & 83,28 & 81,92 & 83,97 & 77 & Китай & 54,48 & 52,07 & 57,15 \\
\hline 3 & Финландия & 82,99 & 82,35 & 83,53 & 78 & Доминиканска реп-ка & 53,51 & 51,97 & 55,25 \\
\hline 4 & Хонконг & 82,65 & 81,79 & 84,69 & 79 & Италия & 53,46 & 51,81 & 55,47 \\
\hline
\end{tabular}


ИЗВЕСТИЯ НА СЬЮЗА НА УЧЕНИТЕ - ВАРНА

\begin{tabular}{|c|c|c|c|c|c|c|c|c|c|}
\hline 5 & Канада & 82,48 & 81,18 & 84,36 & 80 & Кувейт & 53,43 & 50,80 & 57,06 \\
\hline 6 & Австралия & 81,16 & 80,11 & 81,83 & 81 & Словения & 53,39 & 51,13 & 56,64 \\
\hline 7 & Великобритания & 81,10 & 78,81 & 83,52 & 82 & Кения & 52,96 & 46,58 & 59,55 \\
\hline 8 & САЩ & 80,50 & 77,54 & 84,35 & 83 & Бутан & 52,59 & 49,11 & 56,59 \\
\hline 9 & Норвегия & 79,02 & 78,32 & 79,96 & 84 & Филипини & 52,54 & 50,45 & 54,69 \\
\hline 10 & Швеция & 78,77 & 75,76 & 83,31 & 85 & Албания & 52,46 & 47,08 & 57,22 \\
\hline 11 & Швейцария & 78,66 & 74,83 & 80,56 & 86 & Есватини & 51,32 & 50,87 & 51,87 \\
\hline 12 & Германия & 76,75 & 75,18 & 78,63 & 87 & Тунис & 51,30 & 46,62 & 59,36 \\
\hline 13 & Дания & 76,42 & 73,39 & 79,97 & 88 & Сърбия & 50,77 & 48,69 & 52,37 \\
\hline 14 & Нидерландия & 73,91 & 72,07 & 75,90 & 89 & Ливан & 50,70 & 45,96 & 55,78 \\
\hline 15 & Малайзия & 73,70 & 70,39 & 77,60 & 90 & Кабо Верде & 50,64 & 48,17 & 55,02 \\
\hline 16 & Австрия & 73,15 & 71,44 & 75,21 & 91 & Азербайджан & 50,52 & 48,31 & 52,38 \\
\hline 17 & ЮAP & 72,99 & 63,56 & 77,17 & 92 & Казахстан & 50,47 & 46,53 & 53,79 \\
\hline 18 & Япония & 72,87 & 70,69 & 73,62 & 93 & Египет & 50,41 & 44,83 & 57,07 \\
\hline 19 & Израел & 72,55 & 67,58 & 77,18 & 94 & Виетнам & 50,14 & 46,64 & 54,15 \\
\hline 20 & Тайван & 71,80 & 69,96 & 73,39 & 95 & Парагвай & 49,64 & 47,71 & 52,26 \\
\hline 21 & Естония & 71,56 & 70,04 & 72,94 & 96 & Йордания & 49,53 & 46,68 & 54,04 \\
\hline 22 & Ирландия & 71,06 & 69,93 & 72,36 & 97 & Русия & 49,09 & 46,55 & 51,87 \\
\hline 23 & Белгия & 69,84 & 68,09 & 71,41 & 98 & Камбоджа & 48,85 & 42,67 & 52,30 \\
\hline 24 & Франция & 69,31 & 67,28 & 71,76 & 99 & Никарагуа & 48,46 & 45,99 & 49,75 \\
\hline 25 & Чили & 68,67 & 66,81 & 71,49 & 100 & Босна & 48,27 & 47,41 & 50,89 \\
\hline 26 & OAE & 68,46 & 66,19 & 72,04 & 101 & Нигерия & 48,16 & 41,03 & 57,29 \\
\hline 27 & Исландия & 68,24 & 66,11 & 70,60 & 102 & Еквадор & 47,84 & 46,14 & 49,12 \\
\hline 28 & Люксембург & 67,45 & 66,17 & 68,37 & 103 & Украйна & 47,62 & 46,66 & 49,83 \\
\hline 29 & Мавриций & 67,33 & 64,68 & 70,16 & 104 & Уганда & 47,45 & 40,92 & 53,81 \\
\hline 30 & Панама & 67,10 & 65,64 & 69,36 & 105 & Монголия & 47,17 & 44,12 & 50,19 \\
\hline 31 & Полша & 67,05 & 63,56 & 70,26 & 106 & Аржентина & 46,88 & 43,20 & 51,00 \\
\hline 32 & Чехия & 66,78 & 62,23 & 70,40 & 107 & Сейшелски острови & 46,63 & 43,07 & 50,71 \\
\hline 33 & Катар & 66,55 & 60,29 & 71,04 & 108 & Молдова & 46,55 & 42,50 & 52,12 \\
\hline 34 & Латвия & 66,44 & 64,16 & 67,74 & 109 & Киргизстан & 46,08 & 44,53 & 48,46 \\
\hline 35 & Литва & 66,21 & 65,46 & 67,32 & 110 & Гамбия & 45,96 & 42,24 & 49,15 \\
\hline 36 & Бахрейн & 65,91 & 64,47 & 67,63 & 111 & Сенегал & 45,62 & 44,43 & 48,52 \\
\hline 37 & Саудитска Арабия & 65,67 & 62,10 & 70,32 & 112 & Пакистан & 45,17 & 41,22 & 47,20 \\
\hline 38 & Корея, Република & 63,86 & 61,53 & 66,02 & 113 & Малави & 45,11 & 40,24 & 53,39 \\
\hline 39 & Испания & 63,57 & 61,05 & 66,82 & 114 & Зимбабве & 44,69 & 42,50 & 46,98 \\
\hline 40 & Словакия & 63,09 & 60,63 & 64,89 & 115 & Лаос & 44,07 & 37,79 & 47,30 \\
\hline 41 & Кипьр & 62,86 & 55,99 & 69,55 & 116 & Танзания & 43,54 & 38,80 & 51,48 \\
\hline 42 & Перу & 62,71 & 61,52 & 64,53 & 117 & Иран & 43,44 & 40,25 & 48,24 \\
\hline 43 & Оман & 62,24 & 59,39 & 67,53 & 118 & Боливия & 43,38 & 41,91 & 47,26 \\
\hline 44 & Намибия & 62,18 & 60,36 & 65,13 & 119 & Габон & 43,04 & 42,03 & 44,24 \\
\hline 45 & Португалия & 62,13 & 57,52 & 66,35 & 120 & Кот д'Ивоар & 41,51 & 38,23 & 44,60 \\
\hline 46 & Унгария & 61,82 & 57,98 & 65,56 & 121 & Белиз & 40,98 & 40,98 & 40,98 \\
\hline 47 & Мексико & 61,62 & 56,79 & 64,12 & 122 & Непал & 40,70 & 38,49 & 43,53 \\
\hline 48 & Уругвай & 61,56 & 59,39 & 64,45 & 123 & Гвиана & 40,48 & 38,88 & 41,95 \\
\hline 49 & Коста Рика & 61,50 & 56,97 & 66,23 & 124 & Камерун & 39,92 & 35,84 & 47,31 \\
\hline 50 & Гватемала & 61,46 & 59,53 & 63,22 & 125 & Таджикистан & 39,83 & 33,68 & 45,38 \\
\hline 51 & Руанда & 61,38 & 49,77 & 68,52 & 126 & Бенин & 39,34 & 36,62 & 44,07 \\
\hline 52 & Малта & 61,19 & 57,68 & 63,81 & 127 & Буркина Фасо & 39,12 & 37,06 & 41,45 \\
\hline 53 & Индия & 60,60 & 54,44 & 65,96 & 128 & Либерия & 38,90 & 35,54 & 42,85 \\
\hline
\end{tabular}


IZVESTIA JOURNAL OF THE UNION OF SCIENTISTS - VARNA

\begin{tabular}{|l|l|l|l|l|l|l|l|l|r|}
\hline 54 & Тайланд & 60,41 & 58,54 & 63,72 & 129 & Лесото & 38,26 & 33,65 & 42,37 \\
\hline 55 & Барбадос & 60,31 & 55,12 & 65,13 & 130 & Бангладеш & 37,94 & 35,56 & 41,49 \\
\hline 56 & Грузия & 59,99 & 56,22 & 62,32 & 131 & Мозамбик & 37,66 & 34,29 & 39,92 \\
\hline 57 & Хондурас & 59,85 & 56,81 & 62,18 & 132 & Суринам & 37,58 & 34,48 & 40,41 \\
\hline 58 & Ботсвана & 59,59 & 58,08 & 61,60 & 133 & Мали & 37,50 & 35,23 & 39,83 \\
\hline 59 & Ямайка & 59,37 & 52,23 & 65,68 & 134 & Венецуела & 37,35 & 35,10 & 40,80 \\
\hline 60 & Колумбия & 59,02 & 53,83 & 64,40 & 135 & Етиопия & 36,77 & 35,75 & 38,72 \\
\hline 61 & Бруней & 58,82 & 56,51 & 65,08 & 136 & Сирия & 36,23 & 35,52 & 36,94 \\
\hline 62 & Черна гора & 58,65 & 56,08 & 60,39 & 137 & Сиера Леоне & 35,07 & 33,38 & 37,63 \\
\hline 63 & Бразилия & 58,02 & 51,92 & 61,35 & 138 & Гвинея & 33,07 & 28,14 & 44,07 \\
\hline 64 & Турция & 57,98 & 53,66 & 61,87 & 139 & Конго, ДР & 32,57 & 31,52 & 33,62 \\
\hline 65 & Северна Македония & 57,53 & 52,94 & 61,43 & 140 & Мадагаскар & 32,25 & 30,14 & 39,72 \\
\hline 66 & Тринидад и Тобаго & 57,46 & 55,05 & 63,64 & 141 & Мавритания & 29,55 & 26,46 & 33,70 \\
\hline 67 & Шри Ланка & 57,40 & 51,93 & 62,94 & 142 & Алжир & 29,14 & 25,57 & 32,36 \\
\hline $\mathbf{6 8}$ & България & $\mathbf{5 6 , 9 4}$ & $\mathbf{5 4 , 3 7}$ & $\mathbf{5 9 , 6 7}$ & 143 & Чад & 28,54 & 26,91 & 30,94 \\
\hline 69 & Индонезия & 56,62 & 55,37 & 59,66 & 144 & Бурунди & 26,47 & 24,55 & 29,46 \\
\hline 70 & Замбия & 56,01 & 50,70 & 60,31 & 145 & Хаити & 26,23 & 25,09 & 27,66 \\
\hline 71 & Хърватия & 55,98 & 53,68 & 59,23 & 146 & Ангола & 24,65 & 21,38 & 29,42 \\
\hline 72 & Мароко & 55,38 & 53,29 & 56,86 & 147 & Мианмар & 22,39 & 21,29 & 23,25 \\
\hline 73 & Гьрция & 55,15 & 49,75 & 60,96 & 148 & Йемен & 22,06 & 18,62 & 26,60 \\
\hline 74 & Армения & 55,10 & 50,94 & 58,14 & 149 & Либия & 19,80 & 15,54 & 24,93 \\
\hline 75 & Салвадор & 54,75 & 47,94 & 57,52 & & Средно за света & $\mathbf{5 5 , 9 3}$ & $\mathbf{5 3 , 7 6}$ & $\mathbf{5 7 , 0 0}$ \\
\hline
\end{tabular}

Източник: Собствено проучване.

С най-високи средни стойности за периода 2010 г. - 2017 г. са страни с англосаксонски тип финансова система, както и скандинавски страни. Високоразвитата финансова инфраструктура е едно от обясненията за силния финансовия сектор там и подчертава нейната важност за финансовото развитие. България заема 68-мо място и има средни стойности на индекса $(56,94)$, които са близки до средното за света $(55,93)$. Като цяло страната изостава от лидерите, където индексьт е доста по-висок - близо и над 80 за първите десет. На дъното на класацията са страни, в които са налице въоръжени конфликти и/или държавите почти не функционират. В тази връзка ясно се вижда, че финансовата инфраструктура зависи от нормалното функциониране на публичните и частните институции ${ }^{1}$.

Като цяло нивото на финансовата инфраструктура в отделните страни не тьрпи големи колебания през разглеждания период. Свидетелство за това е, че разликата между максималната и минималните стойности за осемте години в повечето случаи не надхвърля 10 единици, като средната разлика е 6,48 . Това се обяснява с относително бавната промяна в компонентите на финансовата инфраструктура. За нейната по-значителна промяна са необходими няколко години, дори и десетилетия.

Анализът на развитието на финансовата инфраструктура може да се допълни чрез стойностите и динамиката на IFI по отделни региони, представени на фиг. 1.

Очаквано най-добра финансова инфраструктура имат развитите страни от Организацията за икономическо сътрудничество (ОИСР) и Европейския съюз (ЕС). Найсилно изостава Южна Азия и Субсахарска Африка. При повечето региони има известна динамика на индекса, но в края на периода той е приблизително на същите равнища, както в началото, което потвърждава извода, за относителната стабилност на развитието на финансовата инфраструктура. Изключение прави ЕС, при който IFI спада от 68,85 през 2010

\footnotetext{
1 Съществената роля на институциите за развитието на финансовите пазари е разгледана по-подробно в
} (Naydenova, 2015). 
г. до 66,45 през 2017 г.

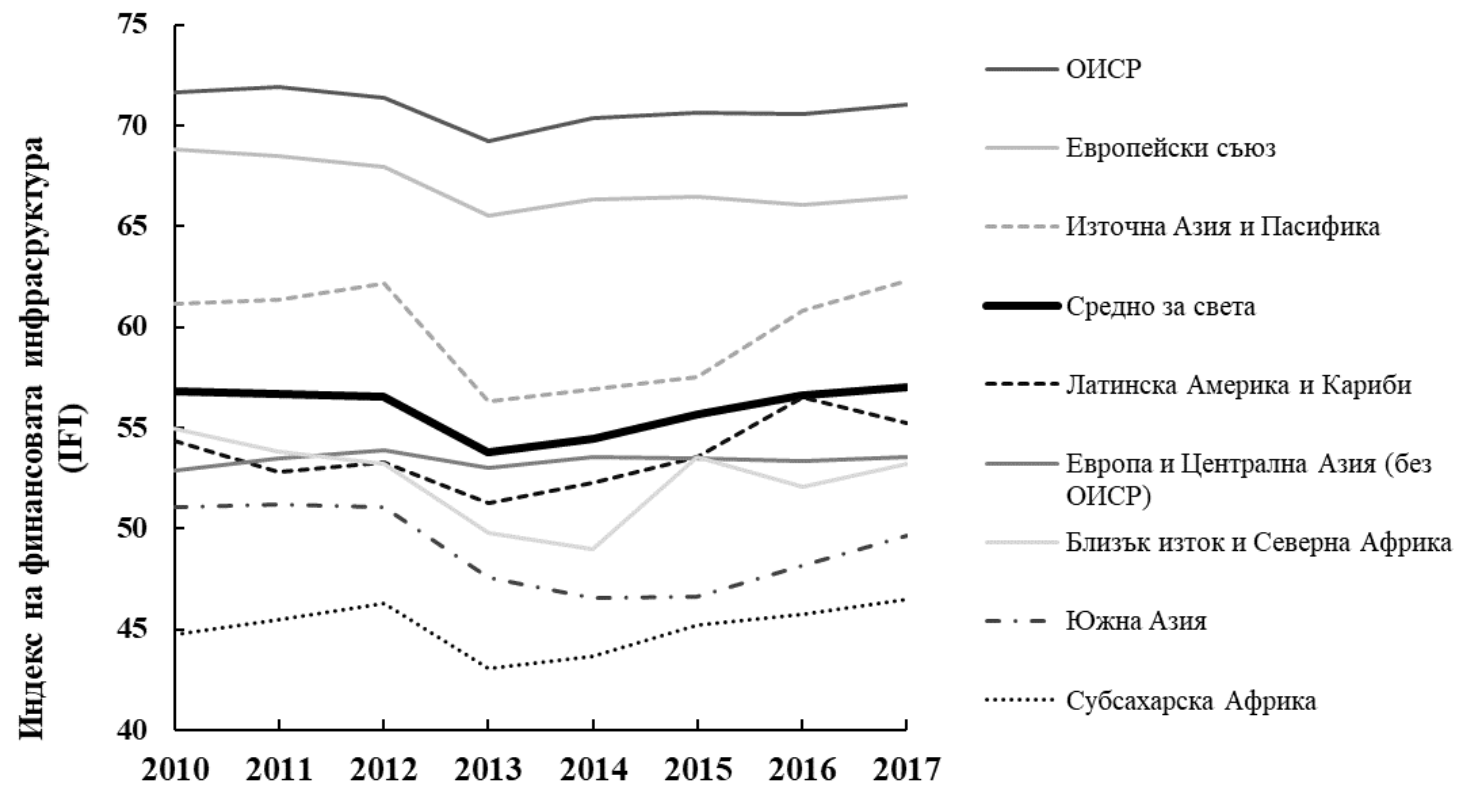

Източник: Собствено проучване Фигура 1. Развитие на финансовата инфраструктура по региони

Финансовата инфраструктура има връзка и с нивото на доходи в отделните страни, която ясно проличава от фиг. 2.

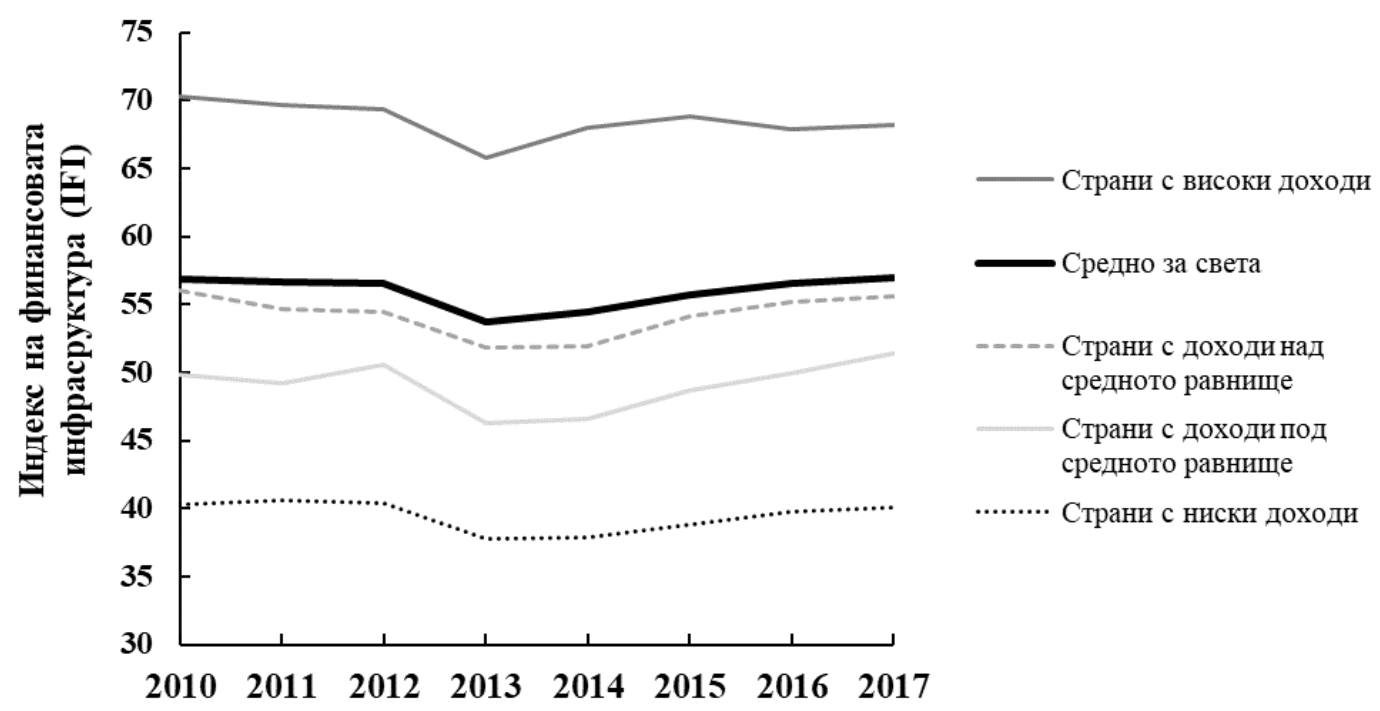

Източник: Собствено проучване

Фигура 2. Развитие на финансовата инфраструктура според нивото на доходи

Страните с по-развита финансова инфраструктура имат и по-висок доход на човек от населението. В това отношение ясно се открояват най-богатите и най-бедните страни, като индексът на финансовата инфраструктура на страните с най-високи доходи е средно със 74\% по-висок в сравнение с този на страните с най-ниски доходи. В динамика отново няма силни изменения през отделните години, като за повечето групи страни нивата на индекса в началото и края на периода са близки. Само при страните с високи доходи се наблюдава известно влошаване, като между 2010 г. и 2017 г. IFI спада от 70,29 до 68,25. От друга страна по-видимо подобрение на финансовата инфраструктура има за страните с доходи под 
средното равнище - от 49,89 до 51,38.

\section{2. Финансовата инфраструктура в България}

За България развитието на финансовата инфраструктура е близко до средното за света както като равнище, така и като динамика (фиг. 3). Като негативни могат да се отбележат две тенденции. Първо, за разглеждания период има леко влошаване, като индексьт на финансовата инфраструктура спада от 59,67 през 2010 г. до 57,81 през 2017 г. Второ, равнището на развитие на финансовата инфраструктура значително изостава от това на средното за ЕС. За разглеждания период индексът IFI за България е средно с 10 единици понисък.

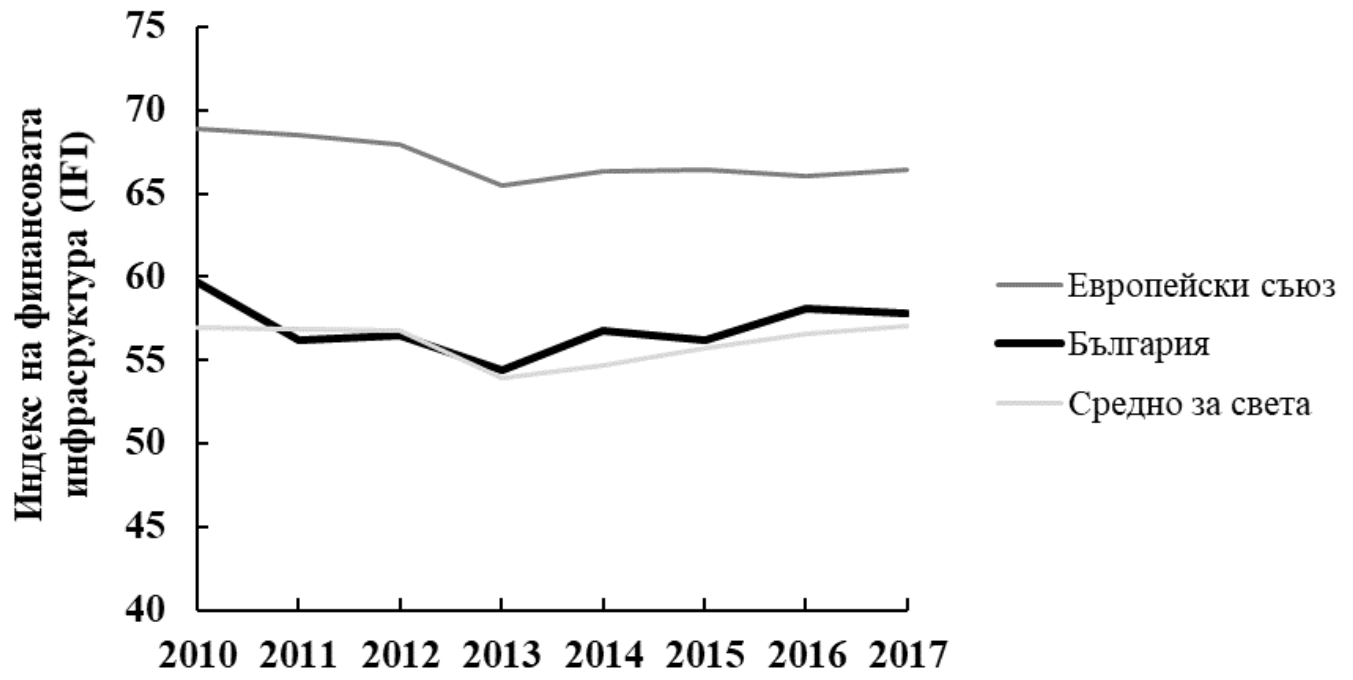

Източник: Собствено проучване

Фигура 3. Развитие на финансовата инфраструктура в България

Силните страни и проблемните моменти във финансовата инфраструктура у нас могат да се разкрият чрез анализ на компонентите на индекса IFI, представени на фиг. 4.
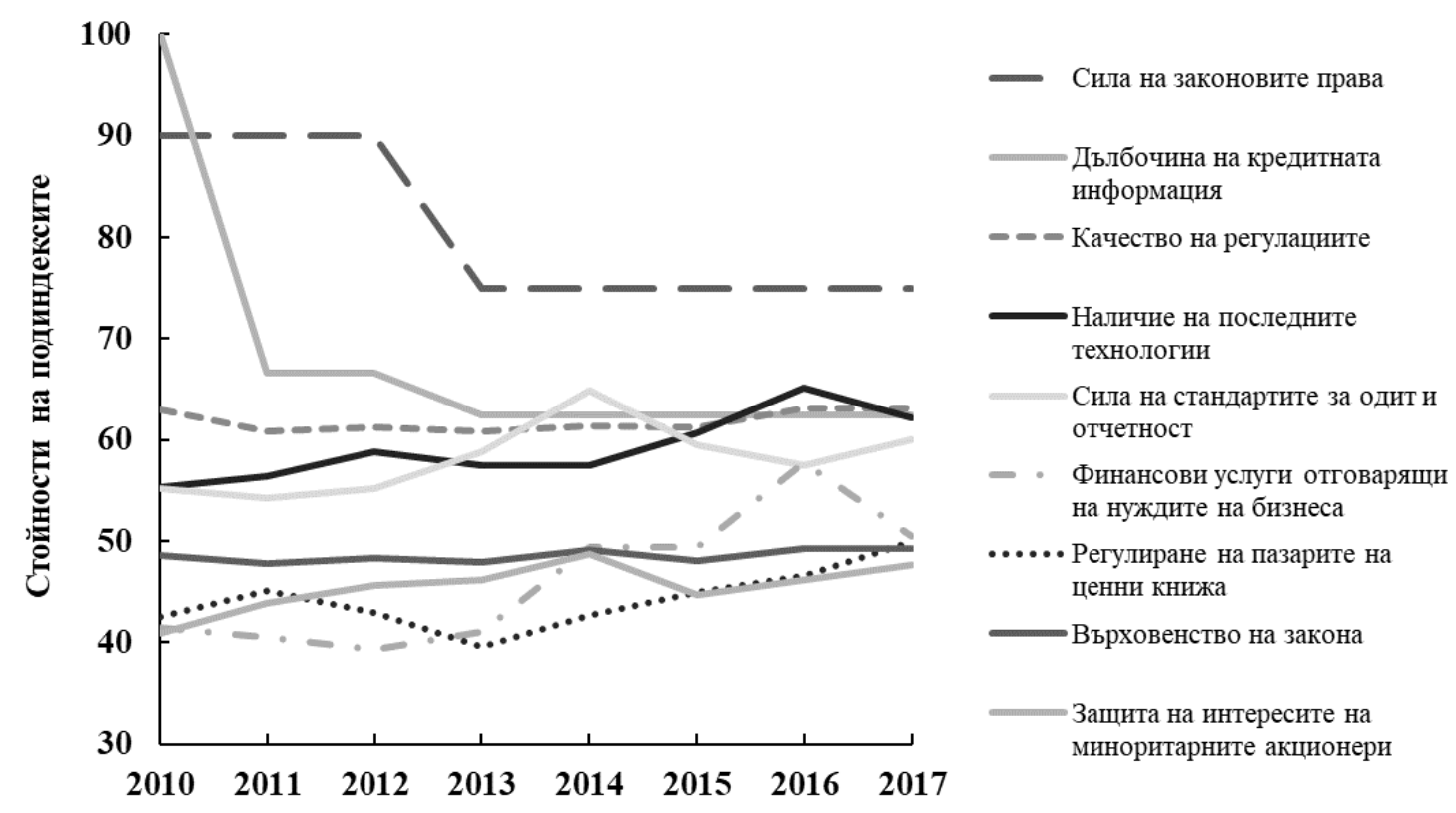

Източник: Собствено проучване

Фигура 4. Компоненти на индекса на финансовата инфраструктура (IFI) в България 
Компонентът с най-високи стойности е сила на законовите права, което показва, че у нас защитата на правата на кредиторите е относително висока. Това е единственият елемент на финансовата инфраструктура, който е значително по-висок от средното за ЕС. Тук основна роля имат банките, които се възползват от голямата си неформална власт и успяват да прокарват интересите на кредиторите при приемането и прилагането на законодателството. С много високи стойности през 2010 г. е бил показателят за дълбочина на кредитната информация, но той бележи рязък спад и допринася за влошаване на финансовата инфраструктура през периода 2011 г. 2013 г. Макар и с ниски начални стойности, най-голям прогрес бележат наличието на последните технологии, предоставянето на финансови услуги отговарящи на нуждите на бизнеса и регулирането на пазарите на ценни книжа. До голяма степен това може да се обясними с все по-голямата връзка на бизнеса и финансовата система в рамките на ЕC, както и хармонизирането на регулациите относно финансовите пазари в него.

Най-лошо е състоянието на защитата на интересите на миноритарните акционери и върховенството на закона. Докато при първия показател все пак има подобрение и намаляване на разликата спрямо средното за ЕС, при втория положението е критично ниско. По отношение на върховенството на закона почти няма подобряване, като през всичките години показателят е между $65 \%$ и $68 \%$ от средното за ЕС. Лошото състояние на тези измерители, свързани с правната среда, могат да се обяснят с проблемното функциониране на съдебната система, която не осигурява ефективно, справедливо и безпристрастно прилагане на правилата за всички икономически субекти. В допълнение функционирането на регулаторните органи в България в много случаи е „изкривено“ от политически влияния, злоупотреба с власт и корупция. Това най-силно се отразява на защитата на правата на миноритарните акционери, които не могат да разчитат на държавните органи.

\section{3. Финансовата инфраструктура като фактор за финансовото развитие}

Добрата финансова инфраструктура е условие за по-високо финансово развитие. Самото финансово развитие е явление, което има комплексен характер и неговото измерване трябва да отчита различни параметри. В тази връзка могат да се използват индексите за финансово развитие, които са разработени и изчислявани от Международния валутен фонд (МВФ) (Čihák et al., 2012; Sahay et al., 2015; Svirydzenka, 2016). Тяхна обобщена характеристика е представена в табл. 2.

Таблица 2. Индекси на финансовото развитие.

\begin{tabular}{|c|c|c|}
\hline Индекс & Описание & Изчисляване \\
\hline $\begin{array}{l}\text { Общо } \\
\text { финансово } \\
\text { развитие } \\
\text { (FD) }\end{array}$ & $\begin{array}{l}\text { Отразява общото финансово развитие, което } \\
\text { включва развитието на финансовите } \\
\text { институции и финансовите пазари. Приема } \\
\text { стойности между } 0 \text { и } 1 .\end{array}$ & $\begin{array}{l}\text { Средна стойност от } \\
\text { индексите на развитие на } \\
\text { финансовите институции } \\
\text { (FI) и финансовите пазари } \\
\text { (FM). }\end{array}$ \\
\hline $\begin{array}{l}\text { Развитие на } \\
\text { финансовите } \\
\text { институции } \\
\text { (FI) }\end{array}$ & $\begin{array}{l}\text { Отразява развитието на финансовите } \\
\text { институции (банки, пенсионни фондове, } \\
\text { взаимни фондове, застрахователни компании) } \\
\text { в три направления - дълбочина, достъп и } \\
\text { ефективност. Приема стойности между } 0 \text { и } 1 .\end{array}$ & $\begin{array}{l}\text { Средна стойност от индекси } \\
\text { за дълбочина, достьп и } \\
\text { ефективност на } \\
\text { финансовите институции. }\end{array}$ \\
\hline
\end{tabular}




\section{IZVESTIA JOURNAL OF THE UNION OF SCIENTISTS - VARNA}

\begin{tabular}{|l|l|l|}
\hline Развитие на & Отразява развитието на финансовите пазари & Средна стойност от индекси \\
финансовите & (на акции и дългови ценни книжа) в три & за дълбочина, достъп и \\
пазари (FM) & направления - дълбочина, достъп и и & ефективност на \\
& ефективност. Приема стойности между 0 и 1. & финансовите пазари. \\
\hline
\end{tabular}

Влиянието на финансовата инфраструктура върху финансовото развитие може да се изследва чрез панелни регресионни модели с постоянни ефекти, които имат следния вид:

$$
\begin{aligned}
& L F D_{i t}=\alpha_{0}+\beta_{1} I F I_{i t}+\beta_{2} \ln \left(\text { GDPC }_{i t}\right)+\beta_{3} I N F L_{i t}+\beta_{4} F O P E N_{i t}+\beta_{5} \text { TOPEN }_{i t}+\beta_{6} \ln \left(P O P U L_{i t}\right) \\
& +\mu_{i}+v_{t}+\varepsilon_{i t},
\end{aligned}
$$

където:

$\mathrm{LFD}_{\mathrm{it}}$ - финансово развитие на страна i през година $\mathrm{t}$, измервано чрез индексите на: общо финансово развитие (FD), развитие на финансовите институции (FI) и развитие на финансовите пазари (FM);

$\mathrm{IFI}_{\mathrm{it}}$ - индекс на финансовата инфраструктура на страна і през година t;

$\mathrm{GDPC}_{\mathrm{it}}$ - ниво на доход на страна i през година $\mathrm{t}$, измерено чрез БВП на човек от населението;

$\mathrm{INFL}_{\text {it }}$ - инфлация на страна і през година t, измерена чрез дефлатора на БВП;

FOPEN $_{\text {it }}$ - финансова отвореност на страна і през година t, измерена чрез индекса Chinn-Ito ${ }^{2}$;

TOPEN $_{\text {it }}$ - търговска отвореност на страна i през година $t$, измерена чрез съотношението между външната търговия (сумата на вноса и износа) към БВП;

POPUL $_{\text {it }}$ - брой на населението на страна і през година t;

$\alpha, \beta_{1}, \ldots, \beta_{6}-$ оценявани параметри;

$\mu_{\mathrm{i}}$ - индивидуални ефекти;

$v_{\mathrm{t}}$ - времеви ефекти;

$\varepsilon_{\text {it }}-$ грешка.

В панелните модели основната независима променлива е индексът на финансова инфраструктура (IFI), като хипотезата е, че по-високата стойност на индекса ще води до посилно финансово развитие. Доказателство за тази хипотеза ще бъде положителната и значима стойност на регресионния коефициент $\beta_{1}$.

Останалите независими променливи (ниво на доход, инфлация, финансова отвореност, търговска отвореност и население) се използват като контролни, за да се отчетат и другите важни фактори за финансовото развитие, освен финансовата инфраструктура. Тяхното включване е необходимо за да се избегне изместване на оценките на модели, ако се пропуснат значими променливи.

Моделите са оценени на база балансиран панел от данни за страните за които е налице информация за всички променливи през периода 2010 г. - 2017 г. Данните са получени от следните източници:

- индекси за финансово развитие (FD, FI, FM) от Financial Development Index Database на МВФ (IMF, 2019);

- индекс на финансовата инфраструктура (IFI) от собствени изчисления;

- ниво на доход (GDPC), инфлация (INFL), търговска отвореност (TOPEN) и население (POPUL) от World Development Indicators на Световната банка (World Bank, 2019);

- финансова отвореност (FOPEN) от данните на Chinn и Ito (Chinn, Ito, 2019).

Резултатите от проведения панелен регресионен анализ са представени в табл. 3.

\footnotetext{
${ }^{2}$ Вж.: (Chin, Ito, 2006).
} 
Таблица 3. Влияние на финансовата инфраструктура върху финансовото развитие

\begin{tabular}{|c|c|c|c|}
\hline & $\begin{array}{c}\text { Общо } \\
\text { финансово } \\
\text { развитие (FD) } \\
\end{array}$ & $\begin{array}{c}\text { Развитие на } \\
\text { финансовите } \\
\text { институции (FI) } \\
\end{array}$ & $\begin{array}{l}\text { Развитие на } \\
\text { финансовите } \\
\text { пазари (ФМ) } \\
\end{array}$ \\
\hline Финансова инфраструктура (IFI) & $\begin{array}{c}\mathbf{0 , 0 0 1 3} \\
(\mathbf{0 , 0 0 0 5}) * *\end{array}$ & $\begin{array}{c}\mathbf{0 , 0 0 2 1} \\
(\mathbf{0 , 0 0 0 6})^{* * * *}\end{array}$ & $\begin{array}{r}0,0005 \\
(0,0008)\end{array}$ \\
\hline Ниво на доход $(\ln (\mathrm{GDPC}))$ & $\begin{array}{c}0,1026 \\
(0,0390)^{* *}\end{array}$ & $\begin{array}{c}0,1089 \\
(0,0599)^{*}\end{array}$ & $\begin{array}{c}0,0947 \\
(0,0446)^{* *}\end{array}$ \\
\hline Инфлация (INFL) & $\begin{array}{c}-0,0006 \\
(0,0002)^{* *}\end{array}$ & $\begin{array}{c}-0,0009 \\
(0,0003)^{* * *}\end{array}$ & $\begin{array}{r}-0,0002 \\
(0,0004) \\
\end{array}$ \\
\hline Финансова отвореност (FOPEN) & $\begin{array}{l}-0,0026 \\
(0,0037)\end{array}$ & $\begin{array}{r}-0,0050 \\
(0,0049)\end{array}$ & $\begin{array}{r}-0,0001 \\
(0,0046)\end{array}$ \\
\hline Търговска отвореност (TOPEN) & $\begin{array}{r}-0,0002 \\
(0,0002) \\
\end{array}$ & $\begin{array}{c}-0,0005 \\
(0,0003)^{* *}\end{array}$ & $\begin{array}{r}0,0001 \\
(0,0002) \\
\end{array}$ \\
\hline Население $(\ln (\mathrm{POPUL}))$ & $\begin{array}{c}0,1110 \\
(0,0524)^{* *}\end{array}$ & $\begin{array}{r}0,0930 \\
(0,0730) \\
\end{array}$ & $\begin{array}{r}0,1274 \\
(0,0792) \\
\end{array}$ \\
\hline Константа & $\begin{array}{c}-2,3736 \\
(1,0490)^{* *}\end{array}$ & $\begin{array}{r}-2,0662 \\
(1,6152)\end{array}$ & $\begin{array}{l}-2,6463 \\
(1,4762)^{*}\end{array}$ \\
\hline $\mathrm{R}^{2}$ & 0,15 & 0,24 & 0,09 \\
\hline Наблюдения & 672 & 672 & 672 \\
\hline
\end{tabular}

Забележка: в скоби са дадени стандартните грешки на коефициентите. ${ }^{*},{ }^{* *},{ }^{* * *}$ обозначават статистическа значимост при риск за грешка съответно $10 \%, 5 \%$ и $1 \%$.

От резултатите се установява, че по отношение на общото финансово развитие коефициентът пред променливата за финансовата инфраструктура е положителен $(0,0013)$ и статистически значим. Това потвърждава хипотезата, че страните с по-добра финансова инфраструктура ще имат и по-високо финансово развитие. Същата зависимост се наблюдава и по отношение на развитието на финансовите институции, където регресионният коефициент също е положителен $(0,0021)$ и значимостта му е още по-висока. Положително влияние се наблюдава и спрямо развитието на финансовите пазари, но тук не се установява съществена значимост. Макар и по-добрата инфраструктура да благоприятства финансовите пазари, за тяхното развитие по-важни са други фактори. Резултатьт може да се обясни с това, че за да има активна търговия на финансовите пазари, инфраструктурата е необходимо, но не достатъчно условие. За пазарите голямо значение има какво е историческото развитие на страната, какви са рисковите нагласи у спестителите и инвеститорите, традициите и доверието в обществата и др.

От останалите контролни величини най-съществено е влиянието на нивото на доход, като очаквано коефициентьт е с положителни стойности, което свидетелства, че по-богатите страни имат по-развити финансови системи. Друг значим фактор за развитието на цялата финансова система и в частност на финансовите институции е инфлацията, която очаквано влияе негативно. Броят на населението също е важен фактор, като оказва положително влияние.

\section{Заключение}

Финансовото развитие оказва пряко въздействие върху развитието на икономиката, като по-ефективната финансова система съдейства за по-висок икономически растеж и ниво 
на доходи. Важно условие за финансовото развитие е добре функциониращата финансова инфраструктура, чието състояние може да се измери на базата на различни показатели. Анализьт на финансовата инфраструктура в различните страни показва, че като цяло тя е относително стабилна и бавно се променя. От значение за нивото на развитие на финансовата инфраструктура е регионът на страната и нивото на доходи в нея. По отношение на България състоянието на финансовата инфраструктура е близкото до средното за света, като е налице изоставане спрямо ЕС. Основни проблеми се наблюдават по отношение на защитата на интересите на миноритарните акционери и върховенството на закона.

Анализът показва, че финансовата инфраструктура има положително и значимо влияние върху общото финансово развитие, както и това на финансовите институции. Може да се направи извода, че страните трябва да подобряват своята финансова инфраструктура, като по този начин ще постигнат по-добро развитие на своята финансова система.

\section{References}

1. Ang, J. (2008) A Survey of Recent Developments in The Literature of Finance and Growth. Journal of Economic Surveys. 22(3). pp. 536-576.

2. Bossone, B., Mahajan, S., and Zahir, F. (2003) Financial Infrastructure, Group Interests, and Capital Accumulation: Theory, Evidence, and Policy. IMF Working Paper No. 03/24. Washington, DC: International Monetary Fund.

3. Chinn, M. and Ito, H. (2006) What Matters for Financial Development? Capital Controls, Institutions, and Interactions. Journal of Development Economics. 81(1). pp 163-192.

4. Chinn, M. and Ito, H. (2019) The Chinn-Ito Index - A de jure measure of financial openness. [Online] Available from: http://web.pdx.edu/ ito/Chinn-Ito_website.htm [Accessed 01/07/2019]

5. Čihák, M., Demirgüç-Kunt, A., Feyen, E., and Levine, R. (2012) Benchmarking Financial Development Around the World. World Bank Policy Research Working Paper 6175. Washington, DC: World Bank.

6. Dabla-Norris, E, and Srivisal, N. (2013) Revisiting the Link between Finance and Macroeconomic Volatility. IMF Working Paper 13/29. Washington, DC: International Monetary Fund.

7. Demirgüç-Kunt, A. and Levine, R. (2008) Finance, Financial Sector Policies, and Long Run Growth. Commission on Growth and Development Working Paper No 11, Washington, DC: World Bank.

8. Georgiev, L. and Valkanov, N. (2014) Finansovo posrednichestvo. 3-to prerab. i dop. izdanie, Varna: Steno.

9. IMF (2019) Financial Development Index Database. [Online] Available from: https://data.imf.org/?sk=F8032E80-B36C-43B1-AC26-493C5B1CD33B [Accessed 01/07/2019]

10. Levine, R. (2005) Finance and Growth: Theory and Evidence. in: Aghion, P. and Durlauf, S. (ed.), Handbook of Economic Growth, edition 1, volume 1, chapter 12, pp. 865-934.

11. Naydenova, K. (2015) Institutsionalen podhod pri izsledvane na likvidnostta na balgarskiya fondov pazar. Investitsii v badeshteto - 2015: Sbornik dokladi ot deseta nauchno-prilozhna konferentsiya s mezhdunarodno uchastie. Varna: NTS, pp. 160-164.

12. Rafailov, D. (2018) Izmervane na razvitieto na finansovata infrastruktura. Measuring Financial Infrastructure Development. Izvestia Journal of the Union of Scientists - Varna. Economic Sciences Series. Varna: Union of Scientists - Varna. volume 7, issue 2, pp. 13-23. 
13. Sahay, R., Čihák, M., N’Diaye, P., Barajas, A., Bi, R., Ayala, D., Gao, Y., Kyobe, A., Nguyen, L., Saborowski, C., Svirydzenka, K. and Yousefi, S. (2015) Rethinking Financial Deepening: Stability and Growth in Emerging Markets. IMF Staff Discussion Note 15/08. Washington, DC: International Monetary Fund.

14. Svirydzenka, K. (2016) Introducing a New Broad-based Index of Financial Development. IMF Working Paper WP/16/5. Washington, DC: International Monetary Fund.

15. Smith, R. and Walter, I. (2003) Global Banking. 2nd Ed. New York, NY: Oxford University Press.

16. World Bank (2018a) Doing Business 2018. Washington, DC: International Bank for Reconstruction and Development (The World Bank).

17. World Bank (2018b) Worldwide Governance Indicators (WGI). [Online] Available from: http://info.worldbank.org/governance/wgi/index.aspx [Accessed 01/07/2019].

18. World Economic Forum (2018). The Global Competitiveness Report 2017-2018. Geneva: World Economic Forum.

19. World Bank (2019) World Development Indicators. Available from: https://datacatalog.worldbank.org/dataset/world-development-indicators [Accessed 01/07/2019]. 